\title{
The Action Mechanism between Government Debt and Financial Market in China Analysis of China's Twenty Year History Data combined with DAG and SVAR
}

\author{
Xi Luoa \\ School of Economics \\ Central University of Finance and Economics \\ BJ. China \\ Zhimin Zhangb \\ School of Economics \\ Central University of Finance and Economics \\ BJ. China \\ Xue Ting Zhaoc \\ Postal Savings Bank of China, \\ BeiJing Branch, China
}

\begin{abstract}
This paper uses the sample data of financial market, economic prosperity and government debt related indicators from 1997 to 2017 in China, and uses DAG and SVAR models to study the linkage mechanism among macroeconomic variables. The results show that there is a causal relationship between financial market, economic prosperity and government debt, and the former two are the transmitter of volatility factors, the latter is the receiver. In the long run, the impact of global economic and capital market volatility on China's government debt risk is significantly higher than the real estate industry and price level and other domestic factors. Active fiscal policy will make the risk of government debt show a rising trend, it is worth noting that the development of financial markets and economic prosperity can reduce the impact of fiscal policy on the economy, thereby alleviating the risk of government debt.
\end{abstract}

Keyword: Financial market economy boom degree government debt linkage mechanism

\section{I .Research Background}

China's economy in recent years has stepped into a new normal period of development, with slow economic growth, prominent structural problems, high local debt, and high economic development risks. Preventing and defusing systemic risks and deleveraging have become the main keynote of the government's work, especially the macroeconomic impact mechanism of government debt risks. An important measure of government debt risk is the debt ratio, that is, the ratio of the end-of-term balance of government debt to GDP of the current period, which is used to assess the debt risk of government departments, especially the risk of government institutions that bear the ultimate debt-servicing responsibility in the debt crisis.

In the free market era before Keynesianism, the mainstream thought was Ricardo's theory of tax equivalence of Treasury bonds, and the study of government debt was in a secondary position. When discussing whether the fiscal deficit in Ricardo's theory led to inflation, Barrow (1976) argued that if there was no crowding-out effect in the economy, when the growth rate of government debt exceeded the growth rate of output, the economy would experience inflation. Thus, government debt was closely related to other macroeconomic indicators.

Financial sub-markets interact with each other, and financial market is the main starting point of government macro-control reform. It is of great significance to study the interaction mechanism between financial market development and government debt risk. In view of this, the purpose of this paper is to analyze the linkage mechanism between China's financial market, macroeconomic index and government debt. Through the detailed analysis of historical data from 1998 to 2017, the research framework of the relationship among macroeconomic indicators, financial market price and scale indicators and government debt ratio is established. he main contributions of this paper are as follows: Firstly, the domestic research has been changed to focus on the local government liabilities.

60 
This paper studies the full-scale government liabilities including the central government and local government liabilities, and uses BIS statistics of the BIS to measure the government liabilities risk, from China across 1998 and 2. Based on the 20-year historical data of the two international financial crises in 2007, the development track of sovereign debt-to-debt ratio is analyzed in detail. Secondly, the paper constructs a comparatively perfect research framework of the relationship between financial market, economic prosperity and government debt, and analyzes the influence mechanism of price and scale indicators of financial sub-markets on government debt, paying attention to the current situation of the separation of financial market and government debt in the research field. Thirdly, on the basis of the latest literature, we use DAG and SVAR to analyze seven economic indicators and identify the long-term and short-term causality. This study is helpful to understand and identify the budgetary constraints and default risks of Chinese government debt from the perspective of financial markets under macroeconomic conditions, and to design the system of closed-loop management of local government debt.

he structure of this paper is as follows: the second part is literature review; the third part is variable description and model construction; the fourth part is short-term linkage mechanism between financial market, economic prosperity and government debt; the fifth part is long-term linkage mechanism between financial market, economic prosperity and government debt; the sixth part is conclusions and policy recommendations.

\section{Related Literature}

Government debt is one of the important ways for modern countries to deal with unexpected events and safeguard national strength. As early as in the Wealth of Nations (Smith, 1776), it has been specially discussed. Marx criticized and exposed the nature of government debt exploitation, but also affirmed its role in promoting the development of modern finance. He believed that government debt made financial transactions and modern banking system prosperous and developed (Marx, 1867). Historically, more than 200 years of attention has been paid to government debt, and more and more theoretical and empirical breakthroughs have been made in the study of the relationship between government debt and other economic indicators.

\section{II.A. Summary of theoretical research in countries other than China}

The relationship between the first type of government debt and capital market. Deane (1965) emphasized the role of government debt in promoting the development of capital markets during the British Industrial Revolution. By creating "stocks" of emerging investment products, government debt further lubricated the transmission path between savings and investment. Hall (2014) concluded that a stable capital market can reduce the volatility of government debt risk by studying the history of the US fiscal system.

The relationship between the second types of government debt and the money market. North (1989) argued that the Bank of England, as a national bank and intermediary, enjoyed the exclusive right to issue bonds to the government in order to coordinate the relationship between the government and bondholders, which not only strengthened the country's credit, but also promoted a major banking revolution. The common development of public capital market and private capital market can concentrate a large number of personal savings. Cochrance (1995) argued that the increase in government debt could also force monetary authorities to implement expansionary monetary policies, which would lead to inflation by issuing money for fiscal financing. Weingast (1997) argued that public financial institutional arrangements and government credit guarantees for debt repayment not only created a stable market system for government debt, but also promoted the rapid development of private debt markets. Beraanke (1999) argued that an increase in the size of the debt would reduce interest rates and result in a crowding-out of investment, which in turn would lead to a decline in national income, further reducing the scale of investment and leading to a serious economic recession. Arestis et al. (2001) using time series data of different countries regression analysis found that the stock market has a weak impact on economic growth. Beck and Levine (2004) and Wu (2010) based on cross-border data show that there is a causal relationship between stock market development and economic growth. Reinhart and Rogoff (2010) empirical analysis of cross-border data shows that rising debt ratios will lead to a decline in economic growth. Hsll (2014) Considering the financial stability of the United States, stable bond prices can reduce the volatility of government debt risk. 


\section{П.В. Summary of theoretical research in China}

Most of the Chinese scholars' researches on the relationship between financial market and government debt are focused on the analysis of government debt by single index of financial sub-market. Ma Yuyou (2001) believes that economic growth is an important factor affecting government debt risk. Zhao Zhenquan (2004) believes that the development of financial markets through economic growth channels affect government debt risk, but the impact on government debt risk is limited. Bai Qinxian (2006) believes that the core role of financial market development is to improve the allocation of resources, create liquidity and diversified risks, improve the financing structure, and ultimately promote economic growth.

Peng Xiaoquan (2000) pointed out that the stock market and bond market are closely related to the two important financing markets, a sound financing market mechanism can reduce the government debt financing costs and interest burden. Wang Zhaocai (2013) believes that the impact of Chinese government bonds on the money supply mechanism is negligible. Ponzi (2015) believes that the stability of government bond prices can mitigate financial risk volatility, especially during recessions. Pang Xiaobo et al. (2017) constructed four indicators of the financial market, including stock trading volume, government expenditure ratio, economic growth rate and economic boom change, the model between the government and debt burden rate, and discussed the direct channel of the development of China's financial market affecting government debt risk.

However, the existing articles on government debt lack of research on the relationship between government debt, financial development and indicators of economic prosperity, the relationship between the overall financial market and government debt, as well as the literature on various financial sub-markets and government debt.

\section{Variable Description and Model Construction}

\section{III.A. Variable selection}

This paper selects monthly data of seven indicators of financial market, economic prosperity and government debt, including government debt ratio, PPI, real effective exchange rate of Renminbi, credit scale, monthly rise and fall of A-share Shanghai stock index, 30-day interbank lending rate and real estate development investment, covering the period from December 1997 to 2018. In March, a total of 1708 samples were obtained. The data came from the Bank for International Settlements, the People's Bank of China, the National Bureau of Statistics, the Oriental Wealth Choice and Wind databases.

Table 1: seven variable indicators

\begin{tabular}{|c|c|c|c|c|}
\hline & Index name & $\begin{array}{c}\text { Data } \\
\text { frequency }\end{array}$ & $\begin{array}{l}\text { Processing } \\
\text { method }\end{array}$ & data sources \\
\hline 1 & $\begin{array}{l}\text { Government debt ratio } \\
\text { (government debt balance } \\
\text { /GDP) }\end{array}$ & Quarterly data & $\begin{array}{l}\text { Interpolation } \\
\text { functions } \\
\text { interpolate the } \\
\text { number of } \\
\text { quarters into } \\
\text { monthly numbers. }\end{array}$ & BIS \\
\hline 2 & Production price index & monthly data & $\begin{array}{l}\text { No need to deal } \\
\text { with }\end{array}$ & $\begin{array}{l}\text { National Bureau } \\
\text { of Statistics }\end{array}$ \\
\hline 3 & $\begin{array}{l}\text { Real effective exchange rate } \\
\text { of RMB }\end{array}$ & monthly data & $\begin{array}{l}\text { No need to deal } \\
\text { with }\end{array}$ & Wind data base \\
\hline 4 & Domestic credit scale & monthly data & $\begin{array}{l}\text { No need to deal } \\
\text { with }\end{array}$ & $\begin{array}{l}\text { Oriental Wealth } \\
\text { Choice data }\end{array}$ \\
\hline 5 & $\begin{array}{l}\text { A share index rose monthly } \\
\text { decline }\end{array}$ & monthly data & $\begin{array}{l}\text { No need to deal } \\
\text { with }\end{array}$ & $\begin{array}{l}\text { Oriental Wealth } \\
\text { Choice data }\end{array}$ \\
\hline 6 & Interbank 30 day lending rate & monthly data & $\begin{array}{l}\text { No need to deal } \\
\text { with }\end{array}$ & $\begin{array}{l}\text { Oriental Wealth } \\
\text { Choice data }\end{array}$ \\
\hline 7 & $\begin{array}{l}\text { Investment in real estate } \\
\text { development }\end{array}$ & monthly data & $\begin{array}{l}\text { No need to deal } \\
\text { with }\end{array}$ & $\begin{array}{l}\text { National Bureau } \\
\text { of Statistics }\end{array}$ \\
\hline
\end{tabular}

Data sources: Based on analysis and arrangement 


\section{(1) Government debt ratio in China}

In China's government debt ratio (government debt balance / GDP), the government debt balance includes the debt of the central and local governments, and the data comes from the Bank for International Settlements. This paper uses the interpolation method to get the monthly government debt ratio quarterly from December 1997 to March 2018.

\section{(2) Producer price index PPI}

PPI is usually used as an important indicator to predict the degree of economic prosperity, and is also an important basis for formulating relevant economic policies and national economic accounting. Monthly data from December 1997 to March 2018 are obtained directly from the National Bureau of Statistics.

\section{(3) Real effective exchange rate of RMB}

The effective exchange rate of the people excludes the effect of inflation on the change of the value of the currency itself, and reflects the external value and relative purchasing power of the domestic currency comprehensively. It can be used as an early warning index for the study of the currency crisis. Monthly data from December 1997 to March 2018 were obtained from Wind.

\section{(4) Chinese credit scale}

Credit scale as a central bank monitoring index is more difficult, because the central bank acts as a money issuer, but from the point of view of money supply and demand, credit belongs to money demand rather than money supply, M2 = DK + QT, in which: DK means new Renminbi loans, QT means other money demand, such as government bonds, corporate bonds. Coupons, financial bonds and other investment vehicles. From the Oriental Wealth Choice data, we obtained the domestic credit balance monthly data from December 1997 to March 2018.

\section{(5) A share index rose monthly decline}

A shares are issued by Chinese listed companies and are subscribed and traded by domestic institutions, organizations or individuals (excluding investors in Taiwan, Hong Kong and Australia) in Renminbi. With paperless electronic billing, the implementation of the $\mathrm{T}+1$ delivery system is limited to $10 \%$. The A-share index almost keeps pace with the change of stock market. The rise and fall of A-share index is an important index to measure the volatility of China's capital market. The monthly data of A share index from December 1997 to March 2018 were obtained directly from Oriental Fortune Choice.

\section{(6) Interbank offered rate (1M)}

Before 1996, because of the lack of funds in the whole region, the interest rates offered by banks varied greatly, and irregularities frequently occurred. The lending market became the "leakage" channel of the real estate and stock markets, and the funds were "drained" from banks to non-bank financial institutions, the latter "short-term borrowing". With the deepening of interest rate liberalization, interbank lending rate has become the most important interest rate in the money market.

Chibor includes eight varieties: overnight $(\mathrm{O} / \mathrm{N})$, one week (1W), two weeks $(\mathrm{W})$, January (1M), March (3M), June $(6 \mathrm{M})$, September $(9 \mathrm{M})$ and one year (1Y). Considering the monthly data, the January (1M) lending rate is selected. The monthly data from December 1997 to March 2018 were obtained directly from Oriental Fortune Choice.

\section{(7) Investment in real estate development}

The amount of investment in real estate development is an important indicator of the prosperity of the real estate industry. It refers to the housing, factories, warehouses, restaurants, hotels and houses to be demolished, as well as the expenses paid for buildings and supporting facilities (such as resorts, office buildings, office buildings, etc.), including housing and land, developed by real estate companies and other entities. Land development and investment, including investment costs. The monthly data from December 1997 to March 2018 were obtained directly from the National Bureau of statistics.

\section{U.B. Model Building}

In this paper, the directed acyclic graph model DAG is used to analyze the short-term relationships of seven variables. Furthermore, the structural vector autoregressive model SVAR is used to study the long-term relationships among variables. 
Firstly, referring to Pagan and Swart (1995) methods, the ADF tests were performed on seven normalized variables. $\left\{\mathrm{x} \_\mathrm{i} \_\mathrm{t}\right\}$ random sequence is defined: $\mathrm{i}=1,2 \ldots 7, \mathrm{t}=1,2, \ldots 244$ (1) If $\mathrm{x} \_\mathrm{i} \_\mathrm{t}=\mathrm{p} \_\mathrm{x} \_\mathrm{i} \mathrm{t}-1+\mathrm{e}$, where: $|\mathrm{p}|<1$, $\{\mathrm{e}\}$ is a white noise sequence, and $\mathrm{E}[\mathrm{e}]=0, \mathrm{~V}(\mathrm{e})=_{-}<$infinity, $\operatorname{Cov}(\mathrm{e}, \mathrm{e})=\mathrm{u}<\infty$

As the seven variables all meet with $=1$, then the formula (2) becomes a random walk sequence with unit roots. Therefore, the definition is rewritten as follows: $(1-\mathrm{P} \mathrm{L}) \mathrm{x} \_\mathrm{i} \_\mathrm{t}=\mathrm{e}, \mathrm{t}=1,2, \ldots \mathrm{L}$ is a lag operator, $1-\mathrm{p} \mathrm{L}$ is a lag operator polynomial, and its characteristic equation is $1-\mathrm{p} z=0$, root $\mathrm{z}=1 / \mathrm{p}$. In this paper, the maximum lag period of $\mathrm{L}$ is 10 , and the lag period of $\mathrm{L}$ is 5 .The results show that the ADF test value ( $\mathrm{t}$ value) is more than $5 \%$ of the significant level value. If the ADF test is not passed, there is a unit root, which indicates that the sample is unstable sequence. Therefore, after the first-order difference of seven variables, it is found that the zero hypothesis $\mathrm{H} \_0$ of the unit root is rejected at the $1 \%$ significance level, indicating that the sample after the difference is a stationary time series.

Secondly, on the basis of ADF unit root test, VAR model is used to model the difference data of seven variables. The lag term of explanatory variable $\mathrm{x}$ is used to predict the explanatory variable $\mathrm{y}$. In VAR model, the random perturbation term contains the current relationship between variables and explanatory variables. $\mathrm{Yt}=\mathrm{alpha}+$ beta _0Xt + beta _1Xt-1 +... + beta _sXt-s + UT, where $t=1,2, \ldots 244$, the seven variables selected in this paper are taken as explanatory variables and explanatory variables in turn, with a lag period of 10.

Thirdly, based on the perturbation term of VAR model, the DAG method is used to obtain the short-term causality among the variables. The principle of DAG is to judge whether there is synchronous causality between two variables by unconditional correlation coefficient and partial correlation coefficient of perturbation term. This paper uses the PC algorithm proposed by Spirtes and others for reference. Firstly, the algorithm assumes that all variables have connected edges, but the direction is unknown, that is, completely undirected; secondly, the causal relationship is determined by two steps: de-edge and orientation. If the coefficient is large, the edge of the connection is retained, otherwise the edge of the connection is eliminated and the N-2 order partial correlation coefficient is tested. In this paper, Fisher's method is used to test saliency. Suppose $\mathrm{X}$ and $\mathrm{Y}, \mathrm{Y}$ and $\mathrm{Z}$ are adjacent respectively, but $X$ and $Z$ are not adjacent. Suppose $Y$ is not in the separation set of $X$ and $Z$, the result of directed acyclic graph is X_Y_Z.

Finally, the results of DAG are substituted into the SVAR model for short-term constraints, and the variance decomposition is performed to obtain the long-term causality among the seven variables. SVAR model introduces the structural relationship between seven variables based on economic theory into VAR model, and forms an organic dynamic linkage system through seven equations. In the whole system, each variable is affected not only by its own lag term, but also by the other six synchronous variables, $B_{0} y_{t}=\Gamma_{0}+\Gamma_{1} y_{t-1}+\mu_{t}$ 。

\section{Iv. The short-term linkage mechanism of financial market and government debt}

From both short-term and long-term perspectives, this paper explores the impact of liquidity in China's financial markets on government debt under different economic conditions. We test the stationarity and co-integration of the variables in the model, use the first-order difference data to model the VAR, and further use the DAG technology to analyze the residual, so as to obtain the short-term causality between the variables.

\section{Iv. A. dynamic changes in Chinese government debt ratio in the past twenty years}

This paper selects the index of government debt rate calculated by the Bank of International Settlements BIS to measure the risk of government debt. BIS and the Ministry of Finance of China have differences in the statistics of the government debt balance. The government debt of BIS includes three parts: loans, bonds and cash and deposits. The statistical difference between the two institutions is the last "cash and deposits", which is not included in the statistical caliber of the Ministry of Finance. It can be seen that the ratio of government debt in the statistics of the Bank for International Settlements is influenced by both fiscal and monetary policies. China's central government debt includes the liabilities of the central government and subsidiary units responsible for repaying or guaranteeing the liabilities, including central government bonds, loans from international financial organizations and foreign governments, cash and deposits, and funds used for the capital of state-owned enterprises. Local government debt includes non-standard business, such as bank loans, bonds, trust loans, which are repaid or guaranteed by local financing platforms, local government departments and institutions. The funds are used for infrastructure construction and public welfare projects. From 1995 to 2017, except for the data of 1997, 2004, 2008 and 2016, the ratio of government debt has been increasing year by year in the past 23 years. Of particular concern is the sharp increase in government debt ratios in 1999, 2001, 2007 and 2017 
Compared with the previous year. During the two international financial crisis in 1998 and 2008, the change of government debt ratio was similar. In the year of financial crisis, the debt ratio of our government has not increased or even decreased, but in the year after the crisis, the debt ratio of our government has increased significantly. From the change of government debt ratio, the debt ratio in 1998 was $20.6 \%$, which was the same as that in 1997, but in 1999, the government debt ratio rose to $21.8 \%$, an increase of 1.2 percentage points; in 2008, the debt ratio was $27.1 \%$, a decrease of $2.1 \%$ compared with 2007 ; but in 2009 , it rose sharply to $34.5 \%$, an increase of 7.4 percentage points in one year, and the government debt ratio increased by 7.4 percentage points. The growth rate reached its highest level in 20 years in 2009. From the point of view of the fluctuation of regulation and control policies, the debt ratio of the Chinese government has declined after the two financial crises in 1997 and 2007. Among them, the downward deviation of the 1998 crisis is very small, the debt ratio rebounds slightly in the later period, and the macroeconomic regulation and control policies are relatively conservative. The greater the government's macroeconomic regulation and control, the greater the economic rebound in recent years after the crisis. From 2007 to 2016, the size of central and local government debt more than doubled. According to statistics from the Bank for International Settlements, the total government debt by the end of 2016 was 27.33 trillion yuan, which was $36.7 \%$ of GDP in the same period, lower than the EU's $60 \%$ warning line, and the government debt risk was relatively controllable. However, from the perspective of the structure of NGO debt, we need to pay close attention to the high leverage risk of the economy. By the end of 2016, residential sector debt (including bank loans of various maturities) was 27 trillion yuan, accounting for $40.0 \%$ of GDP, which was relatively low; however, non-financial sector debt (including traditional bank credit, financial market debt instruments, shadow banking credit financing) was about 112.5 trillion yuan, accounting for $151.37 \%$ of GDP. \%, this is the main source of China's current debt risk, and it is also a major problem to be solved. How to reduce the level of high leverage will be a long-term and arduous task, the leverage of the non-financial sector can be transferred through the appropriate leverage of residents and government agencies.

Fig.1. Chinese government debt ratio change trend from 1995 to 2017

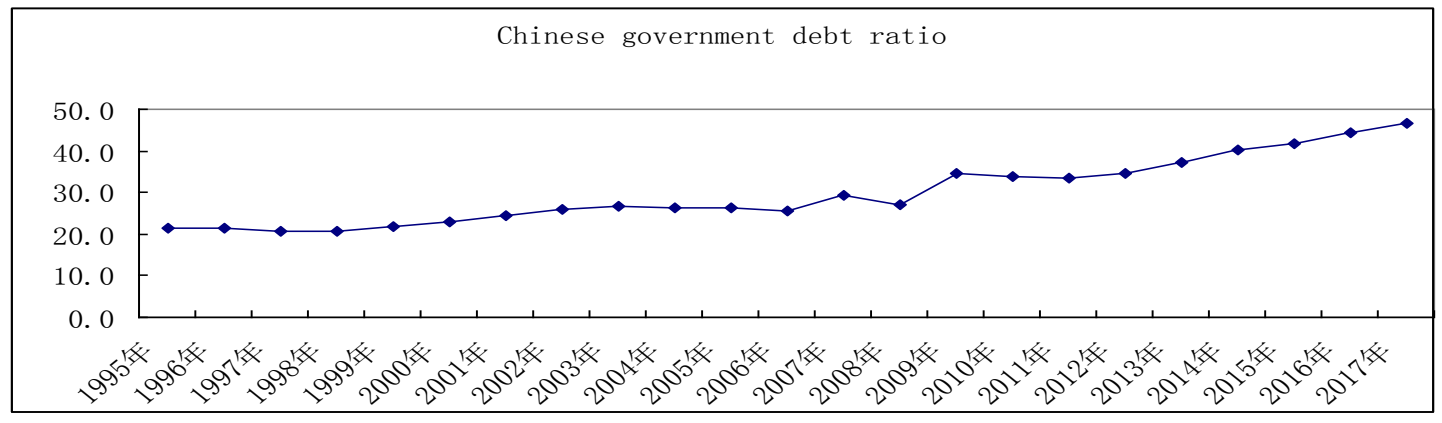

Data source: according to BIS data collation

The central government's financial input is limited, and the main source of funds for managing the economic crisis is debt issuance. In order to stimulate domestic demand, China issued 270 billion yuan of special treasury bonds in 1998, followed by four consecutive years of active fiscal policy. Within four years, the total issuance of government bonds has reached 51 billion yuan, a large number of important infrastructure projects have been concentrated, the embankment of the Yangtze River has been strengthened, new railway lines have been built, the implementation of technical structure and the industrialization of high and new technologies have promoted the continuous upgrading of China's industrial structure. The economic crisis in 2008 led to a sharp drop in external demand, which directly impacted China's export-oriented enterprises, especially raw material processing enterprises, and caused a large number of unemployed people. The central government's financial input is limited, and the main source of funds for managing the economic crisis is debt issuance. In order to stimulate domestic demand, China issued 270 billion yuan of special treasury bonds in 1998, followed by four consecutive years of active fiscal policy. Within four years, the total issuance of government bonds has reached 51 billion yuan, a large number of important infrastructure projects have been concentrated, the embankment of the Yangtze River has been strengthened, new railway lines have been built, the implementation of technical structure and the industrialization of high and new technologies have promoted the continuous upgrading of China's industrial structure. The economic crisis in 2008 led to a sharp drop in external demand, which directly impacted China's export-oriented enterprises, especially raw material processing enterprises, and caused a large number of unemployed people. 
But by the end of 2010 to 2011, the negative impact of the $\$ 4$ trillion stimulus has gradually emerged, a typical example is the excess capacity of cement and steel industries, sales prices began to decline, and the photovoltaic giant Wuxi Suntech Solar Power Co., Ltd. is even facing the threat of bankruptcy.The state's policy management of local government debt is constantly changing, adjusting and improving. In the financial crisis of 2008, in order to maintain growth, the central government supported the financing platform for borrowing from local governments; after the gradual stabilization of the economy in 2010, the financing behavior of the financing platform was strictly controlled in order to control the debt risk; after the economy entered the downturn cycle in 2014, local government bond issuance rights and debt conversion were released to increase steadily. Long to mitigate short-term overdue risks. After 2014, the central government implemented the principle of not covering local government debt, and further standardized the scale and use of local government debt. The new Budget Law gives local governments the right to issue bonds and removes urban investment bonds from local government debt. In 2017, local government debt control was further strengthened. In addition to local bonds under the normal supervision of the central finance, the driving force of local government borrowing by means of city investment and other financing platforms, local state-owned enterprises and PPP projects was basically blocked.

\section{Iv. B. Short term causal analysis of financial market and government debt}

In this paper, the VAR model is built based on the data of seven variables, including government debt ratio, PPI, real effective exchange rate of RMB, domestic credit scale, monthly rise and fall of A-share index, 30-day interbank lending rate and real estate development investment completion, etc. It is estimated by the ECM model. Thus, the following figure 2 is obtained. The residual coefficient matrix of a variable.

\section{Fig. 2: residual coefficient matrix diagram}

$\left[\begin{array}{ccccccr}1 & 0 & 0 & 0 & 0 & 0 & 0 \\ 0 & 1 & 1.823420 & 13.19146 & 0 & 0 & 0 \\ 0 & 0 & 1 & 0 & 0 & 0 & 0 \\ 0.226837 & -17.26496 & 0 & 1 & 0 & 20.87657 & 0 \\ 0.228424 & 0 & 0.202107 & 1.315956 & 1 & 0 & 0 \\ -0.040185 & 99.63933 & 2.517381 & 0 & 10.00157 & 1 & 0 \\ 0.080238 & -0.025606 & 0.017544 & -0.014853 & 0.030358 & -0.019816 & 1\end{array}\right]$

Data source: ECM model estimation result

Fig. 3. short term causality between financial market and government debt

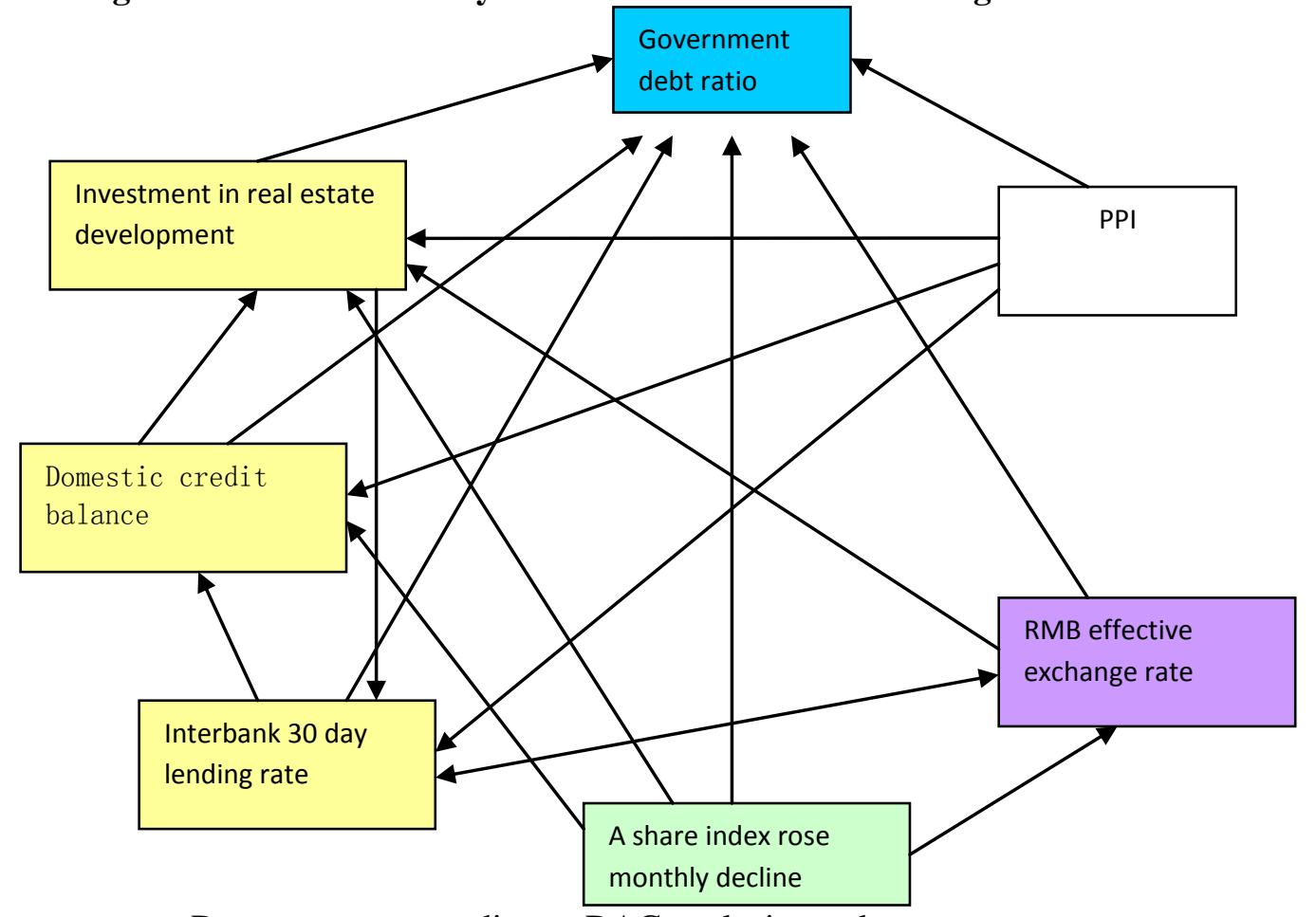


The Fig. 3 shows that there is a concurrent causality between financial market and government debt, including foreign exchange market, capital market, money market, credit market and real estate market. At the same time, there is a concurrent causality between the degree of economic prosperity and government debt. Moreover, the causal relationship between financial market and economic prosperity and government debt is very clear, that is, financial market and economic prosperity is the reason, and government debt is the result.

From the results, we can see that changes in the price and scale of the financial market, as well as the degree of economic prosperity, will improve the tolerance of government debt risk. For macro-control policies, the development of the financial market can effectively utilize the potential savings resources in the economic society, improve the financing environment of the government, and the effectiveness of price transmission in the financial market. The improvement of development level is conducive to expanding the relative scale of government debt in China.

\section{The causal relationship between financial market and government liabilities.}

As far as the whole financial market is concerned, there is a direct causal relationship between the two, in which the price and scale of the financial market is the reason and the government debt is the result. Financial market is composed of two important sub-markets: credit market and capital market. The development of financial market affects the sustainability of government debt through financing capacity, which proves its positive impact on improving the financing environment of government. Financial market can effectively alleviate the fluctuation of equilibrium point of government debt ratio caused by the change of macroeconomic state, and actively prevent and control the periodic systemic risk of the economy. There is not only a direct causal relationship between financial sub-markets and government debt, but also an indirect causal relationship between government debt and other financial sub-markets.

The expansion of Chinese government bonds not only promotes the development of the financial system, but also determines its level of development. The financial market is still in the period of public debt control. Through the interaction between government debt and financial market, a regulatory policy framework has been established. It not only promotes and develops the government's public debt market, but also provides an effective institutional framework for the development of credit market and capital market. At the same time, with the deepening of interest rate marketization, as a low-risk or even risk-free product, the short-term interest rate of government bonds has gradually become the benchmark interest rate of financial markets. The development of financial market will help to promote the virtuous circle of fiscal policy and monetary policy adjustment, expand the turnover rate of macro-control policies, and effectively alleviate the fluctuation of potential economic risks.

\section{Money market and government debt}

Inter-bank lending reflects the short-term lending between commercial banks. It is the bank's behavior of adjusting funds by using the time and space differences in the process of financing. With the promotion of interest rate marketization, the sensitivity of interbank lending rate increases gradually and becomes an important interest rate in the money market. This paper chooses the 30-day inter-bank lending rate to represent the money market price, and analyzes the impact of the money market on government debt combined with the credit scale.

The results show that there are direct and indirect short-term concurrent causality between the 30-day interbank lending rate, domestic credit scale and real estate development investment. The 30-day interbank lending rate fluctuations will directly affect the level of government debt ratio changes, while the price of funds through the impact of bank credit behavior, further promote the change in real estate development investment, and ultimately affect the level of government debt ratio. The scale of bank credit plays an important role in the transmission of interest rate changes to the real economy such as government debt ratio and real estate industry.

\section{Capital market and government liabilities}

The results show that capital market and government debt are closely related. There is not only direct causality but also indirect causality between the monthly rise and fall of A-share index and government debt ratio in the short term. The indirect causal relationship between capital market and government debt is generated through the transmission of RMB real effective exchange rate, real estate development completion and domestic credit scale and other monetary market price indicators and scale indicators. At the same time, government debt can promote the coordinated development of banking and bond market, and promote the modernization of the financial industry. 
The rising government debt ratio in China over the past two decades not only shows the improvement of the government's ability to finance both internally and externally, but also is the result of the development of the banking system and capital market.

The classic theory of interest rate parity explains the linkage between interest rate, exchange rate and stock market volatility. Investors buy stocks with $\mathrm{P}$. The trading price is determined by dividend $\mathrm{g}$, market interest rate $\mathrm{r}$, stock risk rate $\mathrm{K}$ and other factors. The mathematical relationship is that $\mathrm{P}$ is inversely proportional to $\mathrm{R}+\mathrm{k}-\mathrm{g}$, which reflects the rise of $\mathrm{R}$ and leads to the decrease of $\mathrm{P}$. Assuming that capital flows freely internationally, when the interest rate of country A is lower than that of country B, a large amount of money will flow from country A to country B. The interest rate parity theory shows that in the long run, the currency of country A will definitely discount the currency of country B in the foreign exchange market, which is exactly equal to the interest rate difference between the two countries.

The more open the securities market in an economy, the greater the interdependence between the foreign exchange market and the stock market. If the stock price of Country A rises, the exchange rate will cause the exchange rate of Country A to fall, and the interest rate and the exchange rate will change in reverse. This relationship is verified by using the DAG method in the analysis of China's historical data. The exchange rate market as the transmission medium becomes the reason for the change of government debt ratio.

\section{Foreign exchange market and government debt}

The real effective exchange rate of RMB has great influence on the scale and economic structure of China's import and export trade. For example, the effective exchange rate has risen rapidly in the two periods from 1997 to 2002 and from 2008 to the present, and this is also a period of significant decline in the proportion of the secondary industry; on the contrary, in the period of effective exchange rate decline, such as 2003 to 2007, the proportion of the secondary industry rebounded sharply, becoming China's "world factory" period. The reason is that goods and manufacturing are the most international trade industries, while services are the least international trade industries.

The interaction between interest rate and exchange rate is very obvious. At present, China's regulatory interest rate and non market exchange rate constitute the two pillars of the current financial system. If China's GDP growth slows down and international interest rates rise again after interest rate liberalization, China will face a dilemma. On the other hand, domestic interest rates and market integration will aggravate domestic imbalances. Under the framework of this paper, there is no causal relationship between the real effective exchange rate of RMB and the economic boom index PPI. The 30-day interbank lending rate and the effective exchange rate of Renminbi show a causal relationship in the same period, which indicates that the interest rate and exchange rate in China are highly correlated, and the changes between them are mutually restrictive. They both influence the money supply and the internal and external equilibrium of a country. At the same time, there is a causal relationship between the exchange rate and the interest rate and the government debt. Both are the reasons for the change of government debt ratio.

\section{The causal relationship between economic prosperity and government liabilities}

The macro-control policy of our country adopts the mechanism of discretion and adjusts according to the changes of macro-economic indicators. The research shows that there is a direct causal relationship between the degree of economic prosperity and government debt in the same period, and an indirect causal relationship between government debt and the price and scale indicators of the money market. 
Fig. 4: short-term causal relationship between economic prosperity and government debt

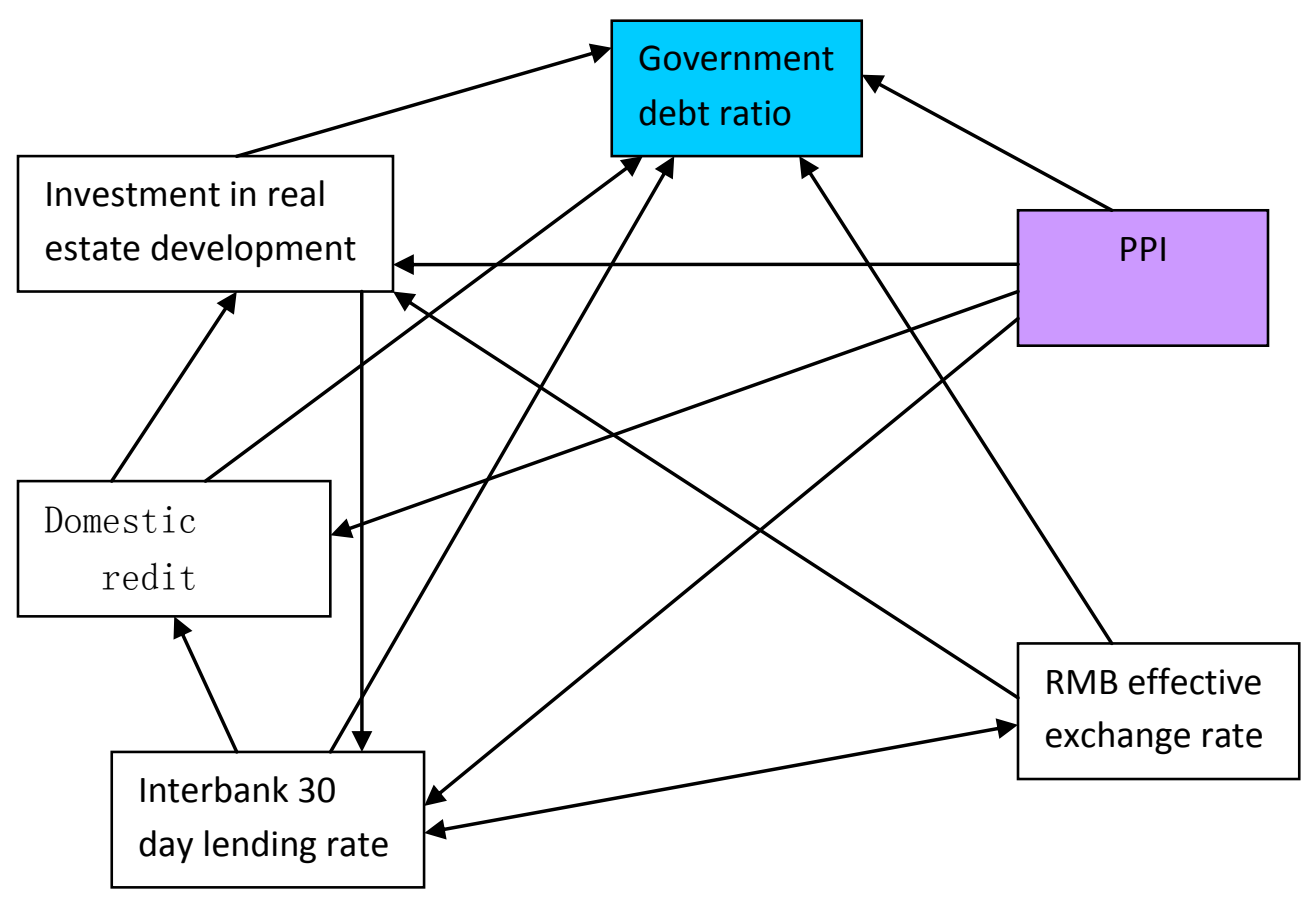

Data sources: according to DAG analysis results

\section{1) Direct causal relationship in the same period}

PPI reflects the overall price level of production. Industrial chain can be divided into two parts: one is the dissemination of industrial products as raw materials, production materials and means of livelihood; the other is the dissemination of agricultural products as raw materials for production, means of agricultural production, agricultural products and food. The fluctuation of the overall price level of the economy usually occurs first in the production field, and then spread to the downstream industries through the industrial chain, eventually affecting consumer goods.

The sharp rise in PPI reflects the country's booming macro-economy, rising national income and consumption capacity. When the price index exceeds the inflation control range, the central bank will tighten the money supply and raise interest rates. The country's economic performance and rising interest rates will increase its currency's international capital. Market attractiveness. On the contrary, if PPI shows negative growth, it shows that the economy is in recession and its consumption capacity is declining. At this time, out of discretion, the country adopted an active fiscal policy to increase the size of government debt, or adopted moderately loose monetary policies such as interest rate reduction, benchmarking and monetary expansion, with the aim of stimulating economic growth.

According to the statistics of the Bank for International Settlements, active fiscal policy and moderately loose monetary policy can increase the size of government debt. Through the above conduction mechanism, PPI has a short-term causal relationship to the government debt ratio.

\section{(2) Indirect causality in the same period}

In order to curb inflation, the central bank will adopt tighter monetary and fiscal policies to raise the benchmark interest rate in the event of a substantial increase in PPI. Inter-bank lending rate will rise on the 30th and domestic credit scale will decrease. As the real estate development funds mainly come from bank credit, accordingly, with the reduction of domestic credit scale, real estate development investment will decline. At the same time, the attractiveness of the country's currency in the international market and the appreciation of the effective exchange rate of $\mathrm{RMB}$ are increasing. 
On the contrary, if a country's PPI shows negative growth, the central bank will reduce interest rates, the 30-day interbank lending rate will fall, in order to stimulate economic growth again, interest rates will fall, economic performance will be depressed, the attractiveness of the currency will decline, the effective exchange rate of the RMB will depreciate. Therefore, the effective exchange rate of RMB affects the change of government debt ratio through the price mechanism of foreign exchange market.

\section{V. the long-term impact mechanism of financial market and government debt}

In order to study the long-term causality, the short-term causal analysis results are substituted into SVAR model as short-term constraints, and variance decomposition is carried out.

V.A. long term causality of SVAR econometric analysis

DAG technique is used to analyze the causality among seven variables. The variance decomposition of SVAR model based on DAG results can give the causality between prediction cycles of each variable. At the same time, the predictive difference decomposition method obtains the economic significance, compared with the DAG analysis method obtains both the economic significance and the statistical significance. In this paper, the above DAG results are substituted as short-term constraints into SVAR models, and structural decomposition is used to obtain long-term causality among seven variables. Table 2 shows the variance decomposition based on the DAG results and the prediction period is 10 periods. The shaded part indicates that the variance decomposition is higher than $5 \%$.

Table 2.SVAR model variance decomposition based on DAG results (\%, prediction period 10$)$.

\begin{tabular}{|c|c|c|c|c|c|c|}
\hline PPI & $\begin{array}{l}\text { RMB } \\
\text { effective } \\
\text { exchange } \\
\text { rate }\end{array}$ & $\begin{array}{l}\text { A share } \\
\text { index } \\
\text { rose } \\
\text { monthly } \\
\text { decline }\end{array}$ & $\begin{array}{l}\text { Interbank } \\
30 \text { day } \\
\text { lending rate }\end{array}$ & $\begin{array}{l}\text { Domestic } \\
\text { redit } \\
\text { balance }\end{array}$ & $\begin{array}{l}\text { Investment } \\
\text { in real estate } \\
\text { development }\end{array}$ & $\begin{array}{l}\text { Government } \\
\text { debt ratio }\end{array}$ \\
\hline \multicolumn{7}{|c|}{ Variance decomposition of government debt ratio } \\
\hline 2.952419 & 0.002324 & 0.023057 & 0.000106 & 0.245694 & 0.0000165 & 638 \\
\hline \multicolumn{7}{|c|}{ Variance decomposition of PPI } \\
\hline 27.77042 & 0.001076 & 0.033874 & 0.0000817 & 0.099194 & 0.0000765 & 72.09528 \\
\hline \multicolumn{7}{|c|}{ Variance decomposition of RMB effective exchange rate } \\
\hline 0.930016 & 0.043063 & 0.106475 & 0.000110 & 4.117612 & 0.00 & 94.80040 \\
\hline \multicolumn{7}{|c|}{ Variance decomposition of monthly rise and fall of A share index } \\
\hline 3.933264 & 0.023863 & 1.946606 & 0.0000978 & 2.169872 & 0561 & 624 \\
\hline \multicolumn{7}{|c|}{ Variance decomposition of interbank 30 day lending rate } \\
\hline 6.575949 & 0.218886 & 0.186525 & 0.001164 & 18.12084 & 0.000186 & 45 \\
\hline \multicolumn{7}{|c|}{ Variance decomposition of credit scale in China } \\
\hline 7.679011 & 0.839917 & 0.042178 & 0.0000978 & 84.59372 & 0.000125 & 6.844951 \\
\hline \multicolumn{7}{|c|}{ Variance decomposition of investment in real estate development investment } \\
\hline 2.347736 & 0.660430 & 0.090224 & 0.003146 & 65.50522 & 0.000484 & 31.39276 \\
\hline
\end{tabular}

Table 3 is a further long-term analysis based on the existence of causal relationship between the seven variables based on table 2. The difference between the results of causality analysis between Table 3 and Figure 2 is that Figure 2 is based on the DAG method and reflects the synchronous causality of the transmission process of volatility factors between financial market variables and government debt. Table 3 is based on the result that the decomposition of DAG variance lags behind 10 periods and is higher than $1 \%$, reflecting the volatility factors between financial market and government debt. Long term causality of prime delivery process.

The results show that there is a short-term causal relationship between the price and scale of the five financial markets and the government debt after the volatility factors, such as the effective exchange rate of RMB, the monthly rise and fall of the A-share index, the 30-day interbank lending rate, the scale of domestic credit and the completion of real estate development investment, and the financial market is The reason is that government debt is the result. From the perspective of long-term and short-term causal analysis, there is a long-term causal 
relationship between the financial market indicators and government debt except the real estate development investment.

Table 3 Risk Transfer in Financial Markets, Economic Prosperity and Government Debt for 10 Months (DAG-based Variance Decomposition)

\begin{tabular}{|c|c|c|c|c|c|c|c|}
\hline & $\begin{array}{l}\text { Government debt } \\
\text { ratio }\end{array}$ & PPI & $\begin{array}{l}\text { RMB effective } \\
\text { exchange rate }\end{array}$ & $\begin{array}{l}\text { A share index } \\
\text { rose monthly } \\
\text { decline }\end{array}$ & $\begin{array}{l}\text { Interbank } 30 \\
\text { day lending } \\
\text { rate }\end{array}$ & $\begin{array}{l}\text { Domestic redit } \\
\text { balance }\end{array}$ & $\begin{array}{l}\text { Investment in real } \\
\text { estate development }\end{array}$ \\
\hline \multicolumn{8}{|l|}{$\begin{array}{l}\text { Government debt } \\
\text { ratio }\end{array}$} \\
\hline PPI & $\sqrt{ }$ & & & & & & \\
\hline $\begin{array}{l}\text { RMB effective } \\
\text { exchange rate }\end{array}$ & $\sqrt{ }$ & & & & & & \\
\hline $\begin{array}{l}\text { A share index rose } \\
\text { monthly decline }\end{array}$ & $\sqrt{ }$ & & & & & & \\
\hline $\begin{array}{l}\text { Interbank } 30 \text { day } \\
\text { lending rate }\end{array}$ & $\sqrt{ }$ & $\checkmark$ & & & & $\sqrt{ }$ & \\
\hline $\begin{array}{l}\text { Domestic redit } \\
\text { balance }\end{array}$ & $\sqrt{ }$ & $\sqrt{ }$ & & & & & \\
\hline $\begin{array}{l}\text { Investment in real } \\
\text { estate development }\end{array}$ & $\sqrt{ }$ & & & & & $\sqrt{ }$ & \\
\hline
\end{tabular}

Data sources: according to DAG analysis results

Note: The first column is the transmitter of risk factors, i.e. the cause of concurrent causality; the first row is the receiver of risk factors, i.e. the result of concurrent causality; indicates the existence of causality.

\section{V.B. Comparison of short and long term Action Mechanism}

Important indicators of financial market development and volatility include the effective exchange rate of RMB, the monthly rise and fall of A-share index, 30-day interbank lending rate, domestic credit scale and real estate development investment, etc. PPI is closely related to the degree of economic prosperity. Comparing the effects of six indicators of long-term and short-term financial market and economic prosperity on the government debt ratio, we find that there are differences in importance ranking.

In the short run, PPI is the most important index, which not only has a direct causal relationship with the government debt ratio, but also affects the government debt ratio through three indirect channels: the 30-day interbank lending rate, the domestic credit balance and the real estate development investment. But in the long run, PPI is less important than RMB. Exchange rate, A share index rose monthly and interbank 30 day lending rate. China's government debt risk is greatly affected by fluctuations in the global economy and capital markets.

The analysis shows that the positive fiscal policy will make the government debt risk increase continuously, and the development of financial market and economic prosperity can reduce the impact of fiscal policy on the economy, thus alleviating the government debt risk. Therefore, when the government adopts fiscal policy to regulate the economy, it can try to combine the development of financial markets with the control of the level of government debt. In addition, government debt risks and economic prosperity need to be addressed. 
Table 4: ranking the importance of financial markets and economic prosperity to government debt

\begin{tabular}{lll}
\hline $\begin{array}{l}\text { Importance } \\
\text { ranking }\end{array}$ & $\begin{array}{l}\text { DAG based financial market and } \\
\text { economic prosperity (short term) }\end{array}$ & $\begin{array}{l}\text { Financial market and economic prosperity } \\
\text { based on variance decomposition (long term) }\end{array}$ \\
\hline 1 & PPI & RMB effective exchange rate (94.80040\%) \\
\hline 2 & A share index rose monthly decline & $\begin{array}{l}\text { A share index rose monthly decline }( \\
91.92624 \%)\end{array}$ \\
\hline 3 & Interbank 30 day lending rate & Interbank 30 day lending rate $(74.89645 \%)$ \\
\hline 5 & RMB effective exchange rate & PPI $(72.09528 \%)$ \\
\hline 6 & Domestic redit balance & $\begin{array}{l}\text { Investment in real estate development } \\
(31.39276 \%)\end{array}$ \\
\hline Data sources: Based on DAG and SVAR measurement results
\end{tabular}

\section{Vi. Conclusion}

This paper calculates the linkage mechanism between government debt and financial market by using DAG and SVAR methods. The results show that government debt is closely related to the changes of financial market and real estate market. Based on the panel data of more than 20 years in China, this paper calculates the causal relationship among the indicators, which provides an important reference for China to implement macroprudential supervision policy. In time dimension, we should monitor the changes of government debt and the price index of financial market, pay close attention to the dynamic changes of China's systemic financial risk, and give early warning. $\mathrm{n}$ the cross-sectional dimension, the government debt should be strictly regulated in the transmission center of systemic risk. Once the government debt ratio exceeds the warning line, the financial market will fluctuate greatly, and even lead to systemic financial risk.

There are three main policy implications: first, a large amount of debt from the central and local governments comes from the financial system, including Treasury bonds, financial bonds and credit products. Accordingly, the government debt crisis will push up interest rates and trigger financial system risks. Therefore, whether from the perspective of macroeconomic stability or financial system stability, we should pay attention to interest rate trends to the policy level, we need to consider the effectiveness of the role of monetary policy, as well as the government debt risk control perspective. Secondly, in order to control the risk of government debt, we need to pay close attention to the short-term capital market. With the liberalization of interest rates and the diversification of financial instruments, money markets play an increasingly important role in conducting the entire financial system. The central bank's monetary policy operation should pay more attention to the credit market and constantly innovate some new policy interest rate instruments to influence market trends. Finally, in terms of debt risk control, we should actively carry out some necessary preparations, including standardizing the bond market, opening up implicit debt, and promoting the construction of debt restructuring procedures, and vigorously promote the reform of local government governance structure.

\section{References}

Ping Xin Qiao, Bai Jie. China's fiscal decentralization and the supply of local public goods [J]. finance and trade economy.2006.2:49-55

Chen Liuqin. Thinking about standardizing the development of local government financing platform [J]. local finance research.2010.11:38-43

Lauren Brandt, Thomas Rawski. Great economic transformation in China [M]. Shanghai people's Publishing House.2009.369-370

Zhu Zhiyong, high-minded. Financial pressure and official performance implications: a detailed study of local government investment and financing platform [J].2010.12:30-35

Qin Hailin. Financial risk financial, financial risk financially and economic growth [J]. Shanghai Finance.2010.3:17-22

Liang Banghai, et al. Comprehensive evaluation system of local government investment and financing platform [J]. economic system reform.2010.4:126-130 
Ma Haitao, Qin Qiang. Improving system construction, strengthening government investment and financing platform management, [J]. economy and management research.2010.1:33-41

$\mathrm{Hu}$ Yuancheng, Zhang Wenjun. [J]. of local government investment and financing platform Reengineering.2010.8:1-4

Tang Yunfeng.Research on the Expansion Mechanism of Local Government Debt in China-Based on the Analysis of Principal-Agent Theory[J].Financial Theory Series.2006.3:54-59

Wang Lianjun. Research on government intervention and bank credit risk under the background of financial crisis [J]. financial research.2011.5:112-122

Peng Xingyun, Shi Huaqiang. Analysis of China's credit expansion under moderately loose monetary policy [J]. economic dynamics.2009.8:45-49

Pan Min, Miao Haibin, Chen Xiaoming. Credit Expansion Behavior of Chinese Commercial Banks under Financial Rescue [J].Journal of Wuhan University.2011.3:93-101

Kornai J., Maskin E., and Roland G. Understanding the soft budget constraint[J]. Journal of Economic Literature, 2003, 41:1095-1136

Shleifer A, Lopez-de-Silanef F, Shleifer A. Government ownership of banks[J]. Journal of Finance, 2002,57: 265-301

La Porta R, Vishny R. Politicians and firms[J]. Quarterly Journal of Economics, 1994,4: 995-1025

Perron P. The Great Crash, The Oil Price Shock and The Unit Root Hypothesis[J]. Econometrica, 1989, 57:

Achaya,V.V.Richardson.M.,Vam Nieuverhurgh,S. ,AND White, L.J.,2011, Guaraked as Fail:Famie Mae,Fredie Mac, and the Dehacle of Martgage Finance, Princton Universtiy Press.

Arhaya,V.,Afono, G.., and Kornoer,A.,2015"How Do Global Banks Scranmble for Liquility Evidence from the Asert-backed Cometcial Pager Frcate of 2001",Jorual of Finacial Intermediation ,forthcoming.

Peter J. Wallison. How and Why a U.S. Sovereign Debt Crisis Could Occur [J]. Econ JournalWatch, 2012,9(1), pp. 71-77.

Philip R. Lane. The European Sovereign Debt Crisis [J]. Journal of Economic Perspectives,2012, 26(3), pp. 49-68.

Pindyck, Robert, and Julio Rotemberg. "The Excess Co-Movement of Commodity Prices[J].The Economic Journal, 1990,100(403), pp. 1173-1189.

Pindyck, Robert, and Julio Rotemberg. The Comovement of Stock Prices [J]. QuarterlyJournal of Economics, 1993,108(4), pp. 1073-1104.

Poon, Ser-Huan, Rockinger, Michael and Jonathan Tawn. Extreme Value Dependence in Financial Markets: Diagnosti cs, Models, and Financial Implications [J]. Review of Financial Studies, 2003, 17(2),pp. 581-610.

Radelet, Steven, and Jeffrey Sachs. The East Asian Financial Crisis: Diagnosis, Remedies,Prospects[C]. Brookings Papers on Economic Activity, 1998, (1),pp. 1-90.

Ricardo Correay, Horacio Sapriza and Andrei Zlate. International Banks and theCross-Border Transmission of Business Cycles [C]. The Federal Reserve Board Seminar,2011.

Rigobon, Roberto. Informational Speculative Attacks: Good News is No News[R]. MIT Mimeo No. 4577,1998.

Rigobon, Roberto. On the Measurement of the International Propagation of Shocks [R].NBER Working Paper No. 7354, 1999.

Roberto A. De Santis. The Euro Area Sovereign Debt Crisis: Safe Haven, Credit Rating Agencies and the Spread of the Fever from Greece, Ireland and Portugal [R], ECB Working Paper No. 1419, 2012.

Ronn, Ehud I. and Avinash K. Verma. Pricing Risk-Adjusted Deposit Insurance: An Option-Based Model [J]. Journal of Finance, 1986,41(4),pp. 871-895.

Rookley,Cameron. Fully Exploiting the Information Content of Intra Day Option Quotes:Applications in Option Pricing and Risk Management [R]. University of Arizona mimeo,1997.146

LongstafF, Francis A. and Eduardo S. Schwartz. A Simple Approach to Valuing Risky Fixed and Floating Rate Debt [J]. Journal of Finance, 1995, 50, pp. 789-819.

Luca Dedola, Giovanni Lombardo. Financial Frictions, Financial Integration and the International Propagation of Shocks [R]. ECB Working Paper, 2009.10.2.

M. Gentile, L. Giordano. Financial contagion during Lehman default and sovereign debt crisis [R]. Consob Working Paper, 2012.12.

M. Gentile, L. Giordano. Financial Contagion during Lehman Default and Sovereign Debt Crisis [R]. CONSOB Working Paper, 2012.12. 
Manski, Charles. Maximum Score Estimation of the Stochastic Utility Model of Choice [J].Journal of Econometrics, 1975, (3), pp. 205-228.

Masson, Paul. Contagion: Monsoonal Effects, Spillovers, and Jumps between MultipleEquilibria[R], IMF Working Paper No. 98/142,1998.

Matteo Ciccarelli, Angela Maddaloni and Jose-Luis Peydro. Heterogeneous Transmission Mechanism Monetary Policy and Financial Fragility in the Euro Area [R]. ECB Working Paper No. 1527, 2012.3.

Mehmed Ganic. The EU Debt Crisis: a Reflection on Financial Sector of the Western Balkans[J]. Journal of Business, Economics \& Finance, 2013, 2(1),pp. 51-64.

Merton, Robert C.. Theory of Rational Option Pricing [J]. Bell Journal of Economics and Management Science, 1973,4 (Spring), pp. 141-183.

Merton, Robert C. and Zvi Bodie. On the Management of Financial Guarantees [J]. Financial Management Journal, 1992,21 (Winter), pp. 87-109.

Mullainathan, Sendhil. A Memory Based Model of Bounded Rationality [R]. University of Maryland Mimeo. No. 6779, 1998.

Nicola Cetorelli, Linda S. Goldberg. Global Banks and International Shock Transmission:Evidence from the Crisis [R], Federal Reserve Bank of New York Staff Report, No. 446,2010.5.145

Rudi Guraziu,Epidamn Zeqo. Sovereign Debt Crisis and its Impact on World Markets [R].IBDE - Integrating World Markets, 2012.6.

Rudiger Dornbusch, Yung Chul Park and Stijn Claessens. Contagion: How it spreads andHow it can be stopped [C]. The WIDER Workshop on Financial Contagion, 2000.5.19.

Rudiger Dornbusch, Yung Chul Park and Stijn Claessens. Contagion: Understanding How It Spreads [J]. The International Bank for Reconstruction and Development, 2000,15(2),pp.97-177.

Rudiger Dornbusch, Yung Chul Park, Stijn Claessens. Contagion: Understanding How It Spreads [J]. The World Bank Research Observer, 2000, 15(2),pp. 177-197.

Sachs, Jeffrey, Aaron Tornell, and Andres Velasco. Financial Crises in Emerging Markets:The Lessons from 1995[C]. Brookings Papers on Economic Activity, 1996, (2), pp. 3-15.

Sebastien Peyrouse. The Impact of the European Debt Crisis on the Partnership with Central Asia [J]. Foreign Policy and Civil Society Program, 2012.5.

Sergio L. Schmukler, Pablo Zoido and Marina Halac. Financial Globalization, Crises, and Contagion [R]. The Globalization World Bank Policy Research Report, 2005.

Stijn Claessens, Kristin Forbes. International Financial Contagion: The Theory, Evidence and Policy Implications [C]. The IMF's Role in Emerging Market Economies: Reassessing the Adequacy of its Resources, 2004.11.15.

Vald es,Rodrigo. Emerging Market Contagion: Evidence and Theory [R]. MIT Mimeo No.5787, 1996.

Valerie De Bruyckere, Maria Gerhardt, Glenn Schepens. Bank/sovereign risk spillovers in the European debt crisis [R]. Working Paper, 2012.9.3.

Vitor Constancio. Contagion and the European debt crisis [J]. ECB Working Paper No.16,2012. 